\title{
Migration Flows and Effects in the CIS Countries-Dynamic Modelling
}

\author{
Alexandr Tarasyev ${ }^{1}$, Gui-Ying Cao $^{2 *}$, Elena Rovenskaya ${ }^{3}$ \\ ${ }^{1}$ University Development, Ural Federal University, Institute of Economics of the Ural Branch of the Russian \\ Academy of Sciences, Yekaterinburg, Russia \\ ${ }^{2}$ Exploratory and Special Projects and Young Scientist Program, International Institute for Applied Systems \\ Analysis, Laxenburg, Austria \\ ${ }^{3}$ Advanced Systems Analysis Program, International Institute for Applied Systems Analysis, Laxenburg, Austria \\ Email: alextarassiev@mail.ru, “cao@iiasa.ac.at, rovenska@iiasa.ac.at
}

Received 27 May 2016; accepted 18 July 2016; published 21 July 2016

Copyright (C) 2016 by authors and Scientific Research Publishing Inc.

This work is licensed under the Creative Commons Attribution International License (CC BY).

http://creativecommons.org/licenses/by/4.0/

(c) () Open Access

\begin{abstract}
Labour migration across countries has been playing a key role in the process of economic integration in the countries of the Commonwealth of Independent States (CIS). The experience of labour migration in CIS appears to be characterized by growing complexity with an increasingly diverse array of countries of origin and destination. The main issues of this paper are: 1) to understand how wage dynamics defined by the labour demand/supply ratio feeds back to migration dynamics, which affects the migration flows between sending and receiving countries over time; 2) to explore how the age structure affects migration flow which in turn effects labour supply in the host country; and 3) to project the potential future migration flow and its impacts on surplus and deficit of labour resource, in order to provide the relevant for migration policies at the both national and regional levels. In this paper we analyse these issues within a dynamic framework; we consider migrant flow into a host region/country at certain moments of time depending on the relationship between expected earnings, costs, and age structure. In addition, we also consider how migration flows interact with natural population growth and age structure in sending and hosting countries.
\end{abstract}

\section{Keywords}

Migration Flow, Dynamic Modelling, Commonwealth of Independent States (CIS), Russia

\section{Introduction}

Labour migration across countries has been playing a key role in the process of economic integration in the ${ }^{*}$ Corresponding author. 
countries of the Commonwealth of Independent States (CIS). As a richer country in the region, Russia receives major immigrants for permanent residence as well as temporary labour migrants. The experience of labour migration in the region appears to be characterised by a growing complexity with an increasingly diverse array of countries of origin and destination. This complexity is not fully explained by economic push-pull factors but rather by the interaction between demographic and economic factors, which co-determine the migration in/out flow.

The main issues of this chapter are: 1) to understand how wage dynamics defined by the labour demand/supply ratio feeds back to migration dynamics, which affects the migration flows between sending and receiving countries over time; 2) to explore how the age structure affects migration flow which in turn effects labour supply in the host country; and 3) to project the potential future migration flow and its impacts on surplus and deficit of labour resource, in order to provide the relevant for migration policies at the both national and regional levels.

In this chapter, we analyse the above issues within a dynamic framework. With this approach, we consider migrant flow into a host region/country at certain moments of time depending on the relationship between expected earnings, costs, and age structure. In addition, we also consider how migration flows interact with natural population growth and age structure in sending and hosting countries.

In this study, the countries include Russia, Ukraine, Tajikistan, Uzbekistan, Kyrgyzstan, Kazakhstan; the analysis especially focuses on three hosting regions in Russia: Moscow, St. Petersburg, and Sverdlovsk; and two sending countries: Kazakhstan and Uzbekistan.

We built our dynamic model of migration flows for analysis and simulation of migration trends. The calibration is based on data from both sending and receiving countries from 2000 to 2012 which are collected from the appropriate national statistics offices.

In the following sections, we will discuss migration relations between Russia and other CIS countries in Central Asia using a dynamic modelling framework. We will also explain how this dynamic model works and how it can examine migration flows. In the last two sections, we will present our preliminary projection results for migration flows up to 2025 and conclude by focusing on the policy implications.

\section{Migration Relations between Russia and Other CIS Countries in Central Asia and the Dynamic Modelling Framework}

There are two reverse tendencies in international migration: on one hand, economic globalisation has led to opening of labour markets. On the other, there is an increasing regionalisation of international migration. Since the 1980s, the CIS in international migration worldwide has increased from 20 to 50 percent (OECD 2010). At present, every second cross-boundary migrant chooses to stay in his/her native region, preferring to migrate to adjacent rather than remote countries. As a result, distinct regional migration systems have emerged, although they often overlap [1].

Eurasian migration is one of the largest regional migration in terms of quantity, along with the North American migration systems, and the European Union systems. Labour migration across countries in the CIS has been playing a key role in the process of regional economic integration and is expected to become even more important in the near future.

Russia effectively maintains its role as the pivot of post-Soviet economic relations in Central Asia. As a richer country of the Eurasian migration system, Russia receives the majority of immigrants in the CIS region. The total number of foreign-born residents in the CIS region is estimated to be between 25 and 30 million people and approximate 12.3 million legal immigrants at the end of the 2000s (World Bank 2011). A popular form of immigration in Russia is temporary labour migration. The Russian labour market includes migrants from over 100 countries; however 80 percent of the labour force is a citizen of a CIS country-especially those originating from Central Asia. Within the Russian quota system in 2011 half of all migrants that were granted work visas were from Uzbekistan $(343,000)$, Tajikistan $(188,000)$, and Kyrgyzstan $(58,000)$. However 13 percent $(153,000)$ of labour migrants originated from China (MPC, 2013).

The experience of labour migration in the CIS region appears to be characterised by growing complexity with an increasingly diverse array of countries of origin and destination. The socio-economic factors which cause or determine migration are often inter-linked, the most important being wage level, living costs, migrant age, labour market situation, and government policy.

Among various factors, wage differentials between sending country and receiving country is a core variable. As it has been shown in the case of the regional migration in the United States, differentials in earnings can in- 
fluence the decision to migrate [2] and increase in the minimum wage can induce migration [3]. A similar situation is evidenced in the CIS region but to a greater degree due to the fact that the average wage in, for example, Tajikistan was just 10 percent of the average Russian wage in the late 2000s, and the average wage in Kyrgyzstan and Uzbekistan was just slightly above 20 percent.

Demographic dimensions are closely associated with migration potential and the CIS countries have undergone different population transition processes over the past decade. Natural population growth, age structure, labour force potential all affect the labour market and migration flows within the region. Unfavourable demographic development in Russia and rapid population growth in some other CIS countries is an important aspect for analysing migration.

Since the beginning of the 1990s, Russia has been suffering from a negative demographic trend. Despite with net migration, Russian between 1990 and 2014 — the population declined by 3.7 million from 1990-2014. Among a number of factors behind the trend Russia, low fertility has been one of major cause for population decline trend. The path of demographic transition in Russia has shown the same pattern like the western industry countries, in 1990s its total fertility was even lower than the western countries with value of 1.25 (see Table 1 , Figure 1 \& Figure 2).

The age structure of Russian population has been aging. Comparing with other CIS countries, Russian population is much older. In the period 2010-2015, Russian population median age 37.8 years, which is 17.5 years and 13.7 years more than Tajikistan and Uzbekistan's populations [4]. While high fertility level remains in the most Central Asia, its population will continue to grow, which will provide a huge potential labour force for re-

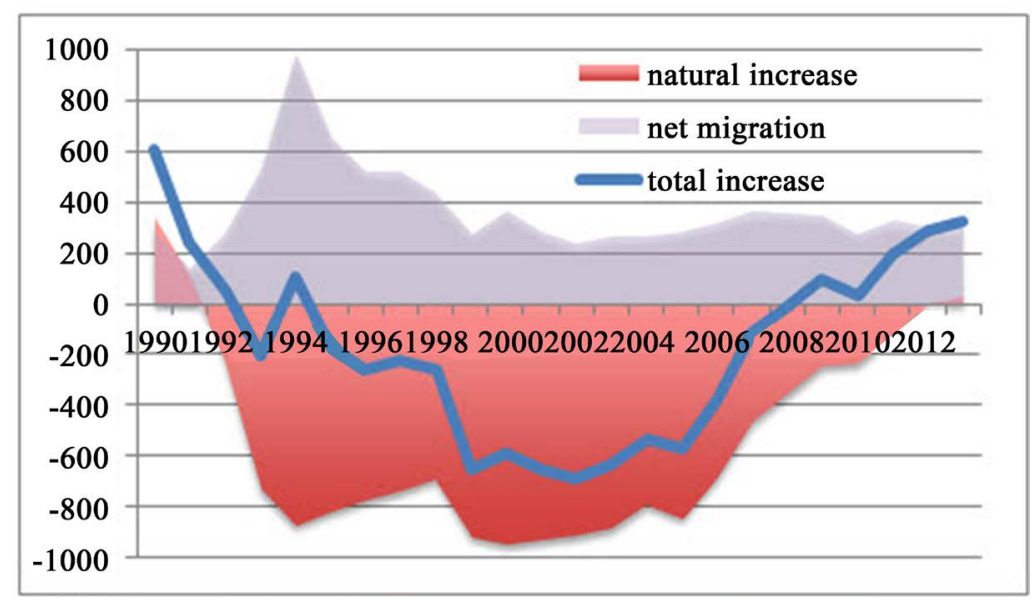

Figure 1. Changes in the population of Russia from 1990-2014.

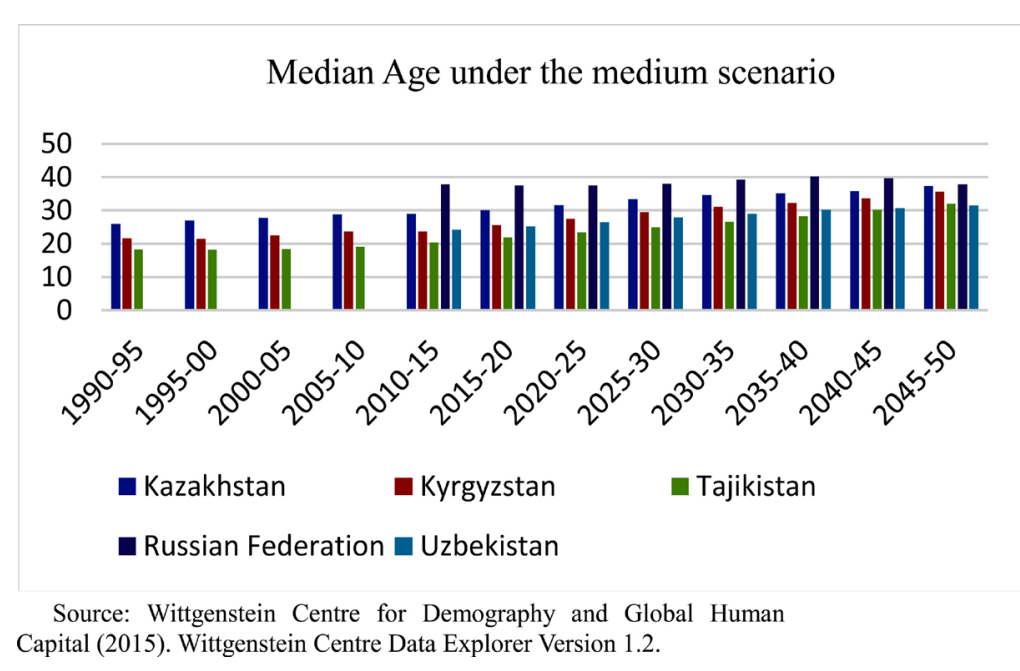

Figure 2. Median age under the medium scenario. 
Table 1. Total fertility rate (TFR).

\begin{tabular}{cccc}
\hline & \multicolumn{3}{c}{ Total fertility per woman } \\
\cline { 2 - 4 } & $1970-1975$ & $1990-1995$ & $2005-2010$ \\
Kazakhstan & 3.5 & 2.6 & 2.5 \\
Kyrgyzstan & 4.7 & 3.6 & 2.8 \\
Tajikistan & 6.8 & 4.9 & 3.7 \\
Turkmenistan & 6.2 & 4.0 & 2.6 \\
Uzbekistan & 6.3 & 3.9 & 2.6 \\
Russian Federation & 2.0 & 1.5 & 1.4 \\
Ukraine & 2.1 & 1.6 & 1.4 \\
\hline
\end{tabular}

Source: Wittgenstein Centre for Demography and Global Human Capital (2015). Wittgenstein Centre Data Explorer Version 1.2.

gional economic growth such as Tajikistan, Uzbekistan and Turkmenistan. According to the Wittgenstein Centre projection by 2050 the population will reach to: in Uzbekistan 35 million, Tajikistan 8.8 million people [5].

The severity of Russia's population decline has been smoothed by a high influx of immigrants from the former Soviet republics.

The major theoretical basics of migration research which we rely on in our study are the flowing:

- The liberal development model assumes the restriction of all barriers for the free movement of the labour force, including labour quotas. This follows the thinking of neoclassical economics which considers the migration decision to be based on the expected gain from the earning gap between the source and host country.

- The neoclassical economic theory of migration is provided with migration models in which immigrant workers respond to cross-region differences in wages, migration costs, and the labor market situation in source and host regions.

- The standard theory of equilibrium which states that the inflow of migrant labour force to a region/country reduces the relative wage of local workers because of the growing level of competition between migrants.

- The human capital model takes into account more migration factors than the classical model of migration such as a fully rational decision on migration depending on the wage gap or the fact of perfect competition on the local labour market.

- Migration networks who help disseminate information about the conditions of life and the labour market situation in different countries/regions, and help in finding employment for involved into these networks migrant workers. The larger is the migration network the more information about the host region is available for other migrants.

- Demographic age transition which looks at the dynamics of the age structure of a population which then may lead to radical changes in the structure of international/internal migration flows and have different impacts on the labour market of a host region.

The liberal development model is focused on all-democratic values. This model is based on a human rights paradigm that prioritizes human rights over citizen rights. The right to free movement is one of the basic human rights in a democratic society (The Universal Declaration of Human Rights 1948) should prevail over a division of rights by a nationality/non-nationality principle in a "pure" liberal model. The liberal development model assumes elimination of all barriers for free movement of the labour force.

Neoclassical theory considers migration as a production factor in a common market. According to neoclassical economics, a migration decision is based on the expected income gained from the earning gap between the source and host country [6] [7]. This concept is built around international differences in wage levels and does not take into account issues of unemployment and the cost of moving, assuming the absolute mobility of the labour force. J. R. Hicks was one of the first to consider migration as a decision made by a rational person capable of making a correct assessment of his/her prospects having access to full and accurate information. The differential in wage levels between different countries which is caused by an uneven distribution of the production factors-labour and capital—is viewed by J. R. Hicks [8] as the incentive to migrate.

As a result, the migratory redistribution helps level wages (income) and stabilise the global labour market in two ways: directly, through the reduction of supply of the labour market of the country with excessive labour 
resources and the increase of supply in the country lacking labour resources, and indirectly through international money transfers made by migrants [9].

However, assumptions arising out of neoclassical economic theory are rather strict and often do not represent the reality on the ground. The following arguments are often presented. First, there is costs are incurred when moving between regions. Second, the assumption of perfect competition is not realised in practice. Imperfect competition in the labour market may manifest itself in the market power of employers over employees. This may result in employers reducing wages without worrying that employees may quit. This power may be fuelled by the heterogeneity of jobs, imperfect information as well as certain costs of employee mobility and/or the creation of new jobs. A reverse situation can occur when employees have market power over employers (for instance when there is a limited supply of labour resources). Differences in the amount of market power in regional labour markets results in wage differentials between them [10].

The logic states that, a rational person decides to migrate when the expected net income resulting from the relocation for a certain period of time exceeds the expected expenditure. The higher the income and the lower the costs mean that people are more likely to migrate. G. F. Tapinos, examining the logic of emigration decision-making, lists the following variables: the potential migrant's total income (nominal wage, income-including - from various types of economic activity), the sum total of consumer spending of the potential migrant (food, housing, clothing, durable goods, healthcare services, recreation, children's education), the amount of savings, levels of prices, and lastly, the probability of obtaining a certain level of income in the country of potential immigration [11].

Human capital theory is commonly used to explain how an economically motivated migration agent behaves [12] [13]. Miron J.R. [14] stresses the importance of understanding the behaviour of potential migrants as information gatherers and decision makers. It is wrong to assume that the potential migrant has perfect information about wages and job availability among all the potential locations involved, and is aware of the extent to which these may reflect disequilibria, especially given that such disequilibria must presumably be changing over time [15].

Migration networks views the transition from individual independence in making the decision to migrate to group interdependence beneficial to all participants was made within the new economic theory of migration. According to this theory, the decision to migrate is made by the potential migrant jointly with other members of his/her family who are changing neither their jobs nor places of residence. By having a family member working abroad, households diversify their sources of income and minimise the risk of losing economic prosperity which — for a family member - may be an incentive for international migration of higher importance than wage differential. Cash transfers are at the same time a source which, if directly invested, strengthens the economic standing of the family or household at the place of their residence. The new economic theory of migration also emphasises the significance of factors such as the level of income of people surrounding the family. Dissatisfaction with one's own social status in the home country may incite family members to migrate with the goal of an increase in income [16] [17].

The demographic transition framework explains migration inflow as a function of the labour power which is needed in a country with a below-replacement fertility rate to fulfil the labour demand. Countries characterised by a low fertility rate necessarily rely on migration flows, thus the decline in fertility and the relative rates of employment growth in neighbouring countries may lead to radical changes in the pattern of international migration [18].

The creation and enlargement of the European Union was one reason for the recent boom in models forecasting international migration patterns. Most are static econometric models [19]-[21]. They chiefly are based on migration rate, population size, employment rate, and income level. In a static setting, only flows from a source country to a host country are considered, ignoring possible return of migrants to the sending country.

When building a dynamic model of migration flows, we have focused on the regional distribution of migrants by country and specified the region, age, wages, and cost of migration. We analyzed the main assumptions of the neoclassical economic theory of migration, the standard theory of equilibrium, the liberal development model, the human capital model, and took into account the influence of migration networks and the demographic age transition on the model behavior. We assume that the main factor if migration increase is the wage gap in analyzed regions and countries. At the same time we assume that the number of potential migrants is based on the idea of migration readiness. The third assumption of our model is that a rational individual tends to maximize his own benefit from migration and will choose a region characterized with a higher salary level and a 
higher life quality level.We address the following questions in the context of Eurasian economic-social development in the following aspects:

- Will there be the labour shortage and how can the labour resource be traded-off with labour in-out flows within CIS countries?

- Will a demographic window of opportunity appear in the Eurasian region due to a big gap in natural population growth among CIS countries?

- How will the wage level be changed in the labour market of both the sending and receiving country as wage level is interlinked with the age structure and the volume of migration?

- What will be the benefit for sending countries in terms of outflow of migration?

\section{Dynamic Model of Migration Flows}

\section{Basic Model}

In this section, we introduce the basic model of dynamic migration. It relies on the following assumptions. First, we assume that migrant flows are directed from a country with lower wages to a region with higher wages; the number of migrant workers is proportional to the wage gap. Second, the assumption is that the wage in a hosting region is based on market principles, i.e., it adjusts to labour demand and supply. Namely, if the available vacancies are not filled by the local unemployed and migrants currently staying in the region, wages go up, thus attracting more migrants from source countries; if, however, the number of migrants is too high so that there are not enough vacancies in the region, wages go down causing return-migration of some migrant workers back to their source countries if the latter provide comparable job opportunities. These two assumptions define the rate of migrant flows between source countries and host regions. Based on this idea, we have constructed a dynamic model which accounts for the total number of migrants in host regions from different source countries year to year. In the following, we describe the mathematical formulation of the basic model in more detail.

We construct a multi-region migration-unemployment-wage model. In the model, time is discrete and its division is indicated as $\Delta>0$, so the length of time is expressed as:

$$
t_{k}=t_{0}+k \Delta(k=0,1,2, \cdots) .
$$

The major assumptions which this study rests on are the closeness of the region with respect to migration outside and the full mobility of the labour force within the region. Due to current visa and labour market regulations, as well as language and other barriers, these assumptions seem to apply to the CIS region.

Let there be $N_{s}$ source countries and $N_{h}$ host regions in the region. We denote the number of labour migrants from the source country $s$ into host region $h$ at time $t_{k}$ by $x_{s h}\left(t_{k}\right)$.

At any time $t_{k}$ a rational person makes a migration decision from source country $s$ to host region $h$ comparing its wage rates, $w_{s}$ and $w_{h}$ respectively. The decision to migrate from source country $s$ to the host region $h$ with certain probability will be positive if the expected benefits due to the earning gap is positive, i.e., if $w_{h}\left(t_{k}\right)-w_{s}\left(t_{k}\right)>0$. If $w_{h}\left(t_{k}\right)-w_{s}\left(t_{k}\right)<0$ a person with certain probability will make a decision on return migration from the host region $h$ to source country $s$ or a decision to move to another host region $h^{\prime}$ for which $w_{h^{\prime}}\left(t_{k}\right)-w_{s}\left(t_{k}\right)>0$.

We assume that the wage rate in a country depends on the relation between vacancies and the total numbers of the labour force, consisting of both locals and migrants. That is, the bigger the gap between the available vacancies and the sum of the local unemployed and migrants, the higher the wages. In case the latter prevails, the number of vacancies and wages decrease. So, we accept the following functional forms to describe the salaries in source and host regions dependent on the migration flows $x_{h}\left(t_{k}\right)$. The wage level in the host region is described by the Equation (1):

$$
w_{h}\left(t_{k}\right)=w_{h}\left(x_{h}\left(t_{k}\right)\right)=w_{0 h} \frac{E_{h}+V_{h}}{E_{h}+U_{h}+x_{h}\left(t_{k}\right)}
$$

where $w_{0 h}$ is the basic wage rate in case of no migration and full employment; $E_{h}$ presents the number of employed; $U_{h}$ is the number of unemployed; $V_{h}$ presents the number of vacancies in host region $h$; and $x_{h}\left(t_{k}\right)=\sum_{s=1}^{N_{s}} X_{s h}\left(t_{k}\right)$ is the total number of migrants in host region $h$.

And the wage level in the source country is described by the Equation (2): 


$$
w_{s}\left(t_{k}\right)=w_{s}\left(x_{s}\left(t_{k}\right)\right)=w_{0 s} \frac{E_{s}+V_{s}}{E_{s}+U_{s}-x_{s}\left(t_{k}\right)}
$$

where $w_{0 s}$ is the basic wage rate in case of no migration and full employment; $E_{s}$ describes the number of employed; $U_{s}$ presents the number of unemployed; $V_{s}$ is the number of vacancies in source country $s$; and, finally, $x_{s}\left(t_{k}\right)^{s}=\sum_{h=1}^{N_{h}} X_{s h}\left(t_{k}\right)$ is the total number of migrants that have left source country $S$.

When making a migration decision a rational person will not only seek to improve their expected income, but also to decrease the migration costs. Earlier research on population migration has already demonstrated that a large distance increases the financial and psychological migration costs and make obtaining information harder [22]; so in the simplest case, the distance between host region $h$ and source country $s$ can serve as a proxy to describe the migration cost. In this study we introduce variable $q_{s h}$ which describes migration costs.

Migrant networks which act as information promoters for their compatriots in the labour market also have a significant impact on decision to migrate. The development of these networks depends on the number of migrants already staying in host region $h$ from the same source country $s$, so we assume that a migration decision at depends on $x_{s h}\left(t_{k}\right)$. On the other hand, the migration flow from source country $s$ is limited by the number of its potential migrants $P_{s}$ wanting to move to another country for temporary work. In order to capture the two latter assumptions, we employ the logistic growth law.

Thus, in a basic dynamic multi-region, the migration-unemployment-wage model was suggested so that to incorporate the abovementioned main assumptions as follows:

$$
\begin{gathered}
x_{s h}\left(t_{k+1}\right)=x_{s h}\left(t_{k}\right)+\Delta q_{s h} x_{s h}\left(t_{k}\right)\left(P_{h}-x_{h}(t)\right)\left(w_{h}\left(t_{k}\right)-w_{s}\left(t_{k}\right)\right), \\
s=1, \cdots, N_{s}, h=1, \cdots, N_{h}
\end{gathered}
$$

where $x_{s h}\left(t_{k}\right)$ is the migration flow; $w_{h}\left(t_{k}\right)-w_{s}\left(t_{k}\right)$ describes the wage gap between regions; $P_{h}-x_{h}(t)$ describes the decreasing potential of migrant workers in the host region; $q_{s h}$ is the coefficient of migration attractiveness of the host region.

\section{Age-Grouped Model}

In this section we extend the above model (Equations (1)-(3)) to take into account the age of migrants and the population growth rate. We specify the flows to/from by three age groups of migrant, each group with its natural growth (fertility and mortality). Three groups are within the age of economic activity (15 - 59).

Y (15 - 29)-Younger-age group

M (30 - 44)-Middle-age group

O (45 - 59)-Older-age group

Below, we provide the full mathematical formulation of the extended model with the three age groups.

We denote via $x_{s h}^{a}\left(t_{k}\right)$ the number of labour migrants of age group $a=\mathrm{Y}, \mathrm{M}, \mathrm{O}$ from source country $s$ in host region $h$ at time $t_{k}$. In the same way, all other introduced model variables receive superscript $a$ to refer to the age group $a=\mathrm{Y}, \mathrm{M}, \mathrm{O}$.

So, we assume that wage functions (1) and (2) become age group specific, i.e., of the form:

$$
w_{h}^{a}\left(t_{k}\right)=w_{h}^{a}\left(x_{h}^{a}\left(t_{k}\right)\right)=w_{0 h}^{a} \frac{E_{h}^{a}+V_{h}^{a}}{E_{h}^{a}+U_{h}^{a}+x_{h}^{a}\left(t_{k}\right)}
$$

and

$$
w_{s}^{a}\left(t_{k}\right)=w_{s}^{a}\left(x_{s}^{a}\left(t_{k}\right)\right)=w_{0 s}^{a} \frac{E_{s}^{a}+V_{s}^{a}}{E_{s}^{a}+U_{s}^{a}-x_{s}^{a}\left(t_{k}\right)}
$$

Age differentiation requires inclusion transport flows from a younger-age group to older-age group into dynamic Equation (3) as follows

$$
x_{s h}^{a}\left(t_{k+1}\right)=x_{s h}^{a}\left(t_{k}\right)+\Delta q_{s h}^{a} x_{s h}^{a}\left(t_{k}\right)\left(P_{h}\left(t_{k}\right)-x_{h}^{a}\left(t_{k}\right)\right)\left(w_{h}^{a}\left(x_{h}^{a}\left(t_{k}\right)\right)-w_{s}^{a}\left(x_{s}^{a}\left(t_{k}\right)\right)\right)+\Delta F_{s h}^{a}\left(t_{k}\right)
$$

where the transport flows $\Delta F_{s h}^{a}\left(t_{k}\right)$ for age groups $a=\mathrm{Y}, \mathrm{M}, \mathrm{O}$ are defined as follows. The flow associated with the younger group $F_{s h}^{Y}\left(t_{k}\right)$ contains an incoming component describing teenagers-children of migrants 
of middle (M) and older age (O) groups from source country $s$ to host region $h$ who enter become 15 years old (Y) who, therefore, enter the younger-age group of the labour force. It also contains an outgoing component describing movement of migrants of age 29 years from younger $(\mathrm{Y})$ to the middle-age group (M) once they turn 30 . This results in the following formula:

Y (15 - 29)-Younger age group:

$$
F_{s h}^{Y}\left(t_{k}\right)=\gamma_{s h}^{M} x_{s h}^{M}\left(t_{k}\right)+\gamma_{s h}^{O} X_{s h}^{O}\left(t_{k}\right)-\beta_{s h}^{Y} X_{s h}^{Y}\left(t_{k}\right)-\mu_{s h}^{Y} X_{s h}^{Y}\left(t_{k}\right)
$$

M (30 - 44)—Middle-age group:

The flow associated with the middle age groups $F_{s h}^{M}\left(t_{k}\right)$ contains an incoming component describing movement of migrants of age 29 years from the younger-age group to the middle-age group once they turn 30 . It also contains an outgoing component describing movement of migrants of age 44 years from the middle-age group to the older-age group once they turn 45 , as well as the death rate. This results in the following formula:

$$
F_{s h}^{M}\left(t_{k}\right)=\beta_{s h}^{Y} x_{s h}^{Y}\left(t_{k}\right)-\beta_{s h}^{M} x_{s h}^{M}\left(t_{k}\right)-\mu_{s h}^{Y} x_{s h}^{Y}\left(t_{k}\right)
$$

Finally, the flow associated with the older-age group $F_{s h}^{O}\left(t_{k}\right)$ contains an incoming component describing movement of migrants of age 44 years from the middle-age group to the older-age group once they turn 45 . It also contains an outgoing component describing the movement of migrants of age 59 years from the older-age group once they turn 60 , as well as the death rate. This results in the following formula:

O (45 - 59)-Older-age group:

$$
F_{s h}^{O}\left(t_{k}\right)=\beta_{s h}^{M} x_{s h}^{M}\left(t_{k}\right)-\beta_{s h}^{O} x_{s h}^{O}\left(t_{k}\right)-\mu_{s h}^{O} x_{s h}^{O}\left(t_{k}\right)
$$

One more extension of model (1)-(3) which we adopt in this study takes into account population growth rate in source countries which makes the migration potential $P_{s}$ be time-dependent so that it is defined as follows:

$$
P_{s}^{a}\left(t_{k}\right)=P_{s}^{a}\left(t_{k-1}\right)+g_{s}^{a} P_{s}^{a}\left(t_{k-1}\right)
$$

where $a=\mathrm{Y}, \mathrm{M}, \mathrm{O} ; g_{s}^{a}$ is the natural growth rate of the population.

\section{Calibration Results}

\section{Future Trends of Migration Flows Up to 2025}

The calibration process is based on the dynamic model (4)-(10), using data from national statistic agencies of the countries under consideration and has simulated the dynamics from 2012 until 2025. For illustration, we focus on two CIS sending countries, Kazakhstan and Uzbekistan, as they are Russia's major Central Asian partners; and we choose Moscow as the main receiving region in Russia.

Although we will refine calibration, the preliminary results have shown some obvious characteristics.

The Russian region will continue to be a centre of attraction for migration flows and will benefit from a demographic window of opportunity from CIS countries.

Figure 3 \& Figure 4 demonstrate the calculated trends for total number of migrants of seven countries, while Figure 3 and Figure 4 illustrate trends for Kazakhstan and Uzbekistan by age group. The total number of migrants will increase roughly about 2.5 times over the next 12 years which is equivalent to around eight percent of the average annual growth for Moscow. The result is of particular importance, as Russia, due to its lower fertility rate over the last 20 years has experienced a decline in its domestic workforce, especially in the 15 - 29 age group. The aggregate number of inflow migration in Moscow shows that the younger group is higher than the other two groups, which might be caused by the younger population in the sending countries such as Uzbekistan, Turkmenistan, Tajikistan, and Azerbaijan, their younger age groups are high in sharing of national population components in the next two decades.

The Russian population is experiencing negative growth and rapid ageing (see Figure 1 \& Figure 2). The long-term demographic forecasts show that this trend will continue, with a sharp decline in the economically active population. Due to life expectancy growing steadily since 1996 (after a dramatic decline in the first half of the 1990s) and a declining birth rate, the proportion of the elderly among the Russian population is increasing rapidly. Our results confirm that the continuing trend of massive migration into Russia allows it to enjoy the sufficient labour supply from CIS countries, which are in demographic transition characterized by a higher birth rate and low mortality rate. Given the external demographic window of opportunity, if Russia could institute a 
A. Tarasyev et al.
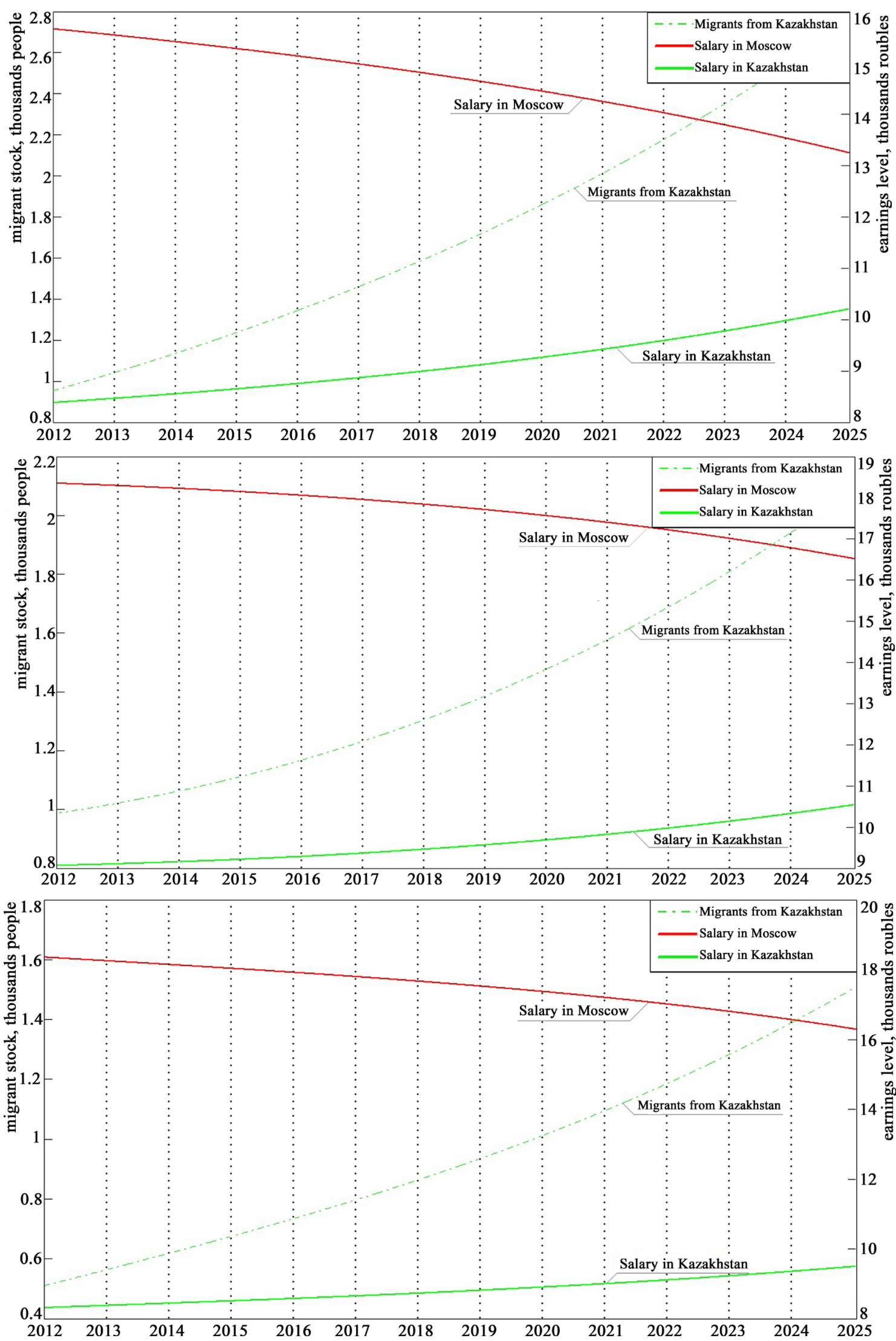

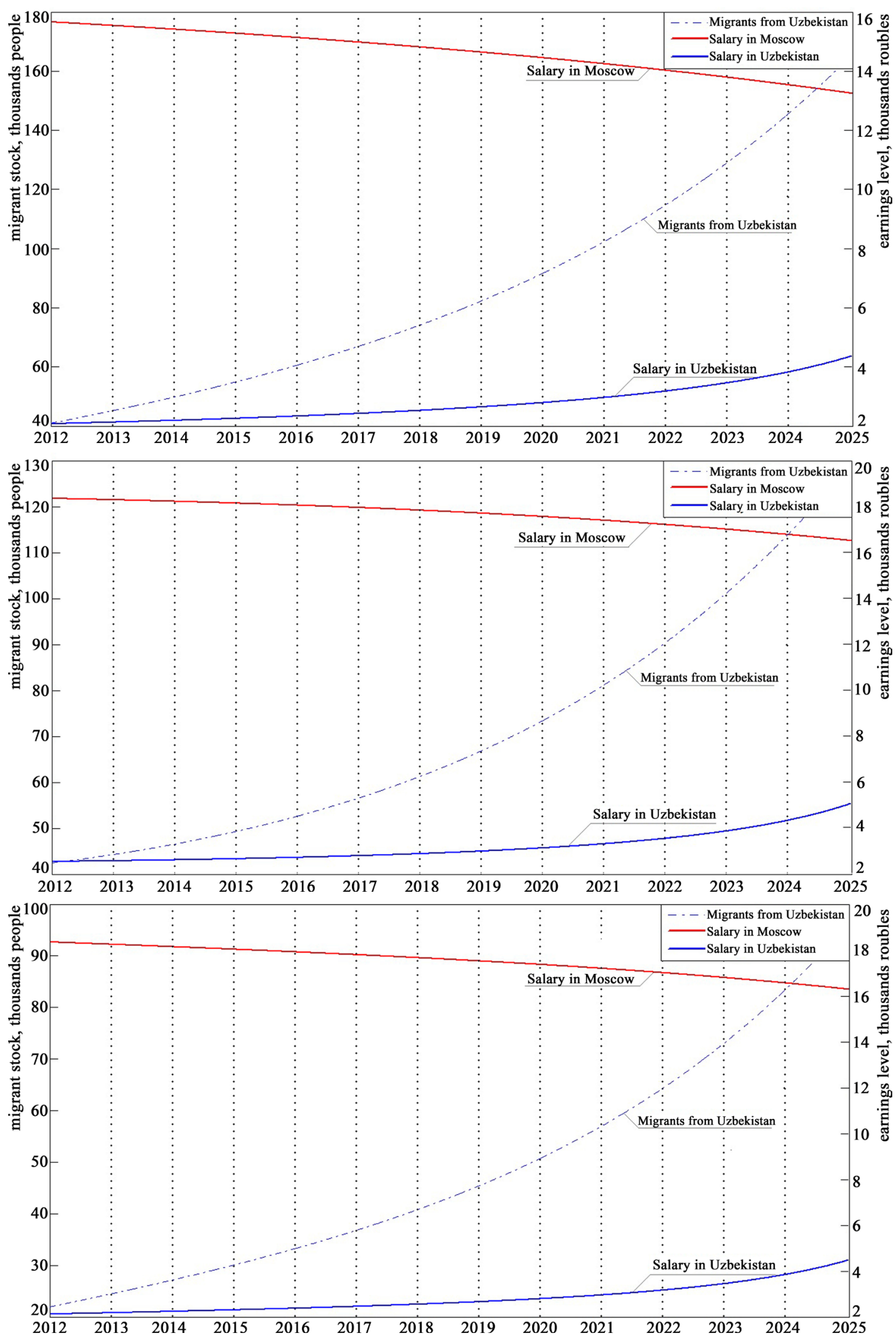

Figure 3. Migration trends (upper plot: younger age group; middle plot: middle age group; lower plot: older age group) from Kazakhstan to Moscow (left column) and from Uzbekistan to Moscow (right column). 

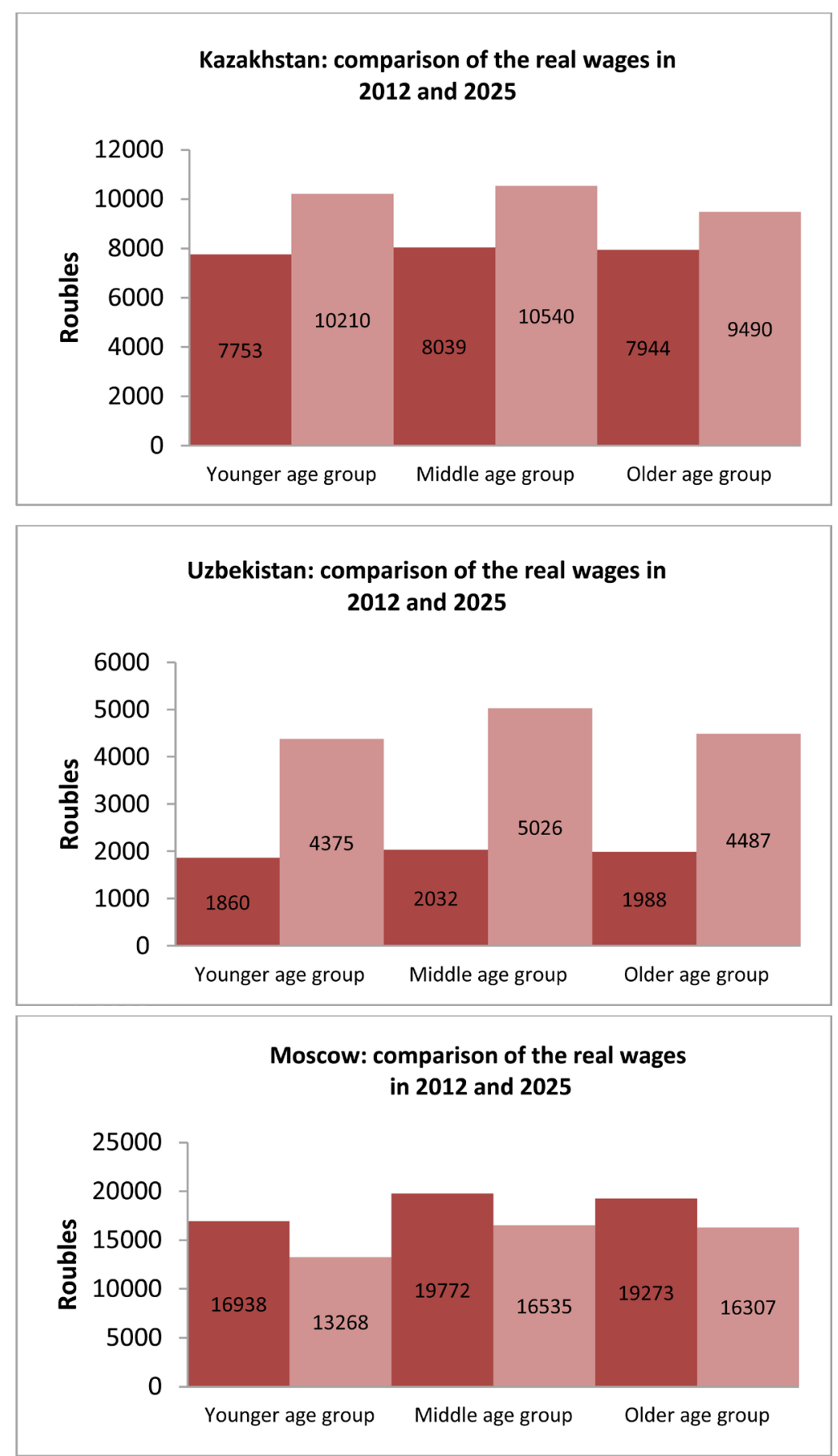

Figure 4. Comparison of the wage levels in Kazakhstan, Uzbekistan and Moscow in 2012 and 2025.

proper immigration policy, it would be of great benefit for further economic growth of that country.

The wage gap between Russian and CIS countries will diminish slowly in the long term, but will continue to cause massive inflows of migrants into Russia over the next decade.

Low wages in Uzbekistan and Kyrgyzstan have made people travel north to Russia. Thus there is no surprise that the results shown in Figure 5 support the World Bank's statement:

The World Bank's global modelling of a three per cent increase in the labour force of high-income countries, due to migrants from developing countries during the period 2001-2025, finds a small decline in average wages for high-income countries but a "barely perceptible” impact on the long-term growth of wages [23] [24]. 

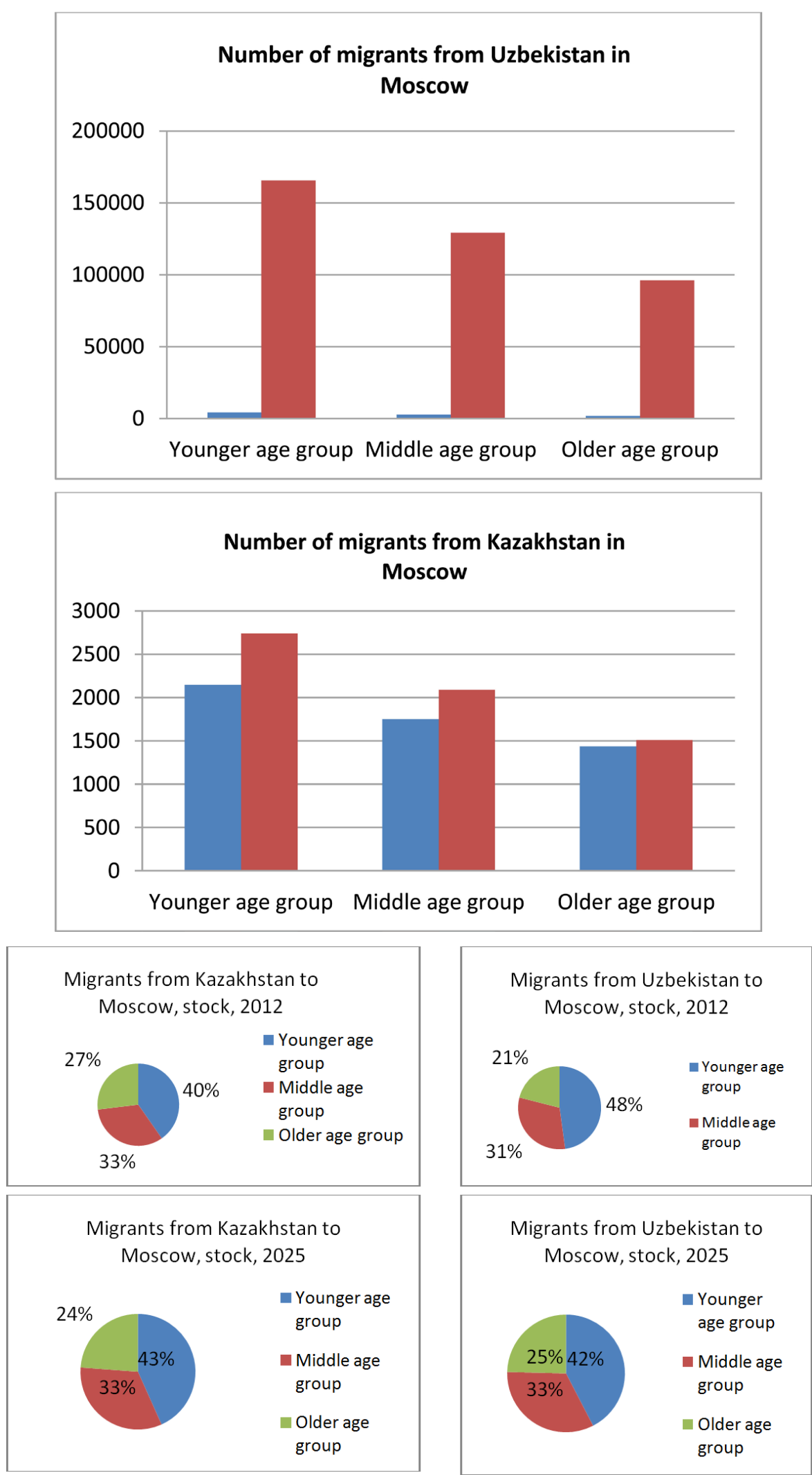

Figure 5. Migrant age transition: comparison of the age structure in 2012 (upper plots) and 2015 (lower plots); migrants from Kazakhstan to Moscow (left-hand side plots) and from Uzbekistan to Moscow (right-hand side plots). 
Our projections indicate that, even though the wage gap between Russia/Kazakhstan and between Russia/ Uzbekistan will tend to diminish up to 2025, this will happen rather slowly; the relatively big gap will still be significant in the next decade, especially the large wage gap between Russia and Uzbekistan in all three age groups. It is necessary to note that the trend of migrations between Kazakhstan and Uzbekistan are different. If the wage differential is closing between the sending and hosting countries, the size of migration is going to be the downward trend, like migration from Kazakhstan to Russia up to 2025.

The wage gap between Russia and CIS countries will diminish, while the wages in the Moscow region will go downward [25]. This tendency however may call for attention to the negative effects on wages and employment due to immigration, where the arguments are that immigrants may compete in labour markets with native-born workers, thus displacing native-born workers, or causing real wages for native-born workers to be pushed down. However, Friedberg and Hunt [26] through surveys refute this argument. These preliminary results need deeper analysis to ascertain the migration impact on both the sending and hosting economies, including dimensions of wage, unemployment, and labour productivity [27].

The sending countries will continue to benefit from remittances due to the wage gap between the hosting regions but to a different extent.

For sending countries, the short-term economic benefit of emigration is found in remittances due to the wage differences between the hosting region and the sending countries. Most of the CIS-sending countries have being receiving sizeable remittances from abroad in the past decades, a consequence of a large Diaspora who is primarily resident in Russia. In Kyrgyzstan total remittances may be as much as 15 percent of GDP and in Uzbekistan as much as 20 percent of GDP.

Figure 3 show the future migration trends and wages according three age groups of Uzbekistan and Kazakhstan. Our results confirm that Uzbekistan and Kazakhstan together with other CIS countries will continue to enjoy the benefit of remittances, which will continue to support their countries' economic growth at least in the short and medium terms [28]. As discussed previously the gap in wage trends between Russia and Kazakhstan, and between Russia and Uzbekistan will diminish gradually in the in long term [29], and that this might affect the future trend of outmigration from Kazakhstan to Russia in both quantity and quality.

- In line with the economic-demographic development process, some CIS countries are likely to switch from being a sending to a receiving country in the medium term.

From past experience, the main trends have been similar from year to year for all CIS countries. Prior to 2008, almost all countries experienced an increase in the outflow of migrants to Russia, but in 2006 the rate of growth was reduced, while in Kazakhstan and Belarus this even became negative. In addition to wage differentials, other factors such as the hosting region's migration policy, unemployment, natural population growth, as well as the sending country's economic situation, all affect the value of migration.

Kazakhstan is a well-off country in the region, and has been one of the five fastest-growing economies in the world in recent years. Its good economic performance has led to a higher wage level than most of other CIS countries. As observed in Figure 5 that in the mid-term time horizon, Kazakhstan is likely to switch from being a sending to becoming a receiving country, and compete for the labour force from other CIS countries.

Naturally, migration flows from Kazakhstan and Uzbekistan to Moscow are different in size, being co-determined by both economic and demographic factors. Uzbekistan will keep its higher migration flow to Moscow, since it natural growth rate of its population is much higher and will continue growing rapidly, while its economy is at a low development stage. The net migratory outflows are low in Kazakhstan because of its relative lower fertility rate, as well as its successful economic performance since 2000. We can see that Kazakhstan has the potential to attract in-flow migrants and may compete with Russia for human resources for its economic development in the next 10 years.

\section{Conclusion and Discussion}

The complexity of migration processes comes from the interaction of economic, demographic, and other social factors, which co-determine the size, age structure, and skill level of migration flows from sending to receiving countries. The analytical tools are needed to simulate the dynamics of the migration processes in a holistic context.

Our dynamic model presented in the chapter is built based on interactions between economic and demographic factors, as well as on interactions between the sending and hosting regions, and is used for the analysis and simulation. This model's most salient characteristic is that it can catch dynamic mechanisms of interacted 
multi-factors in both the sending and hosting regions and countries simultaneously; and it can assess the outflow of migrants and return migrants from sending countries. Such a model is needed urgently in the CIS region during the process of regional economic integration.

To wrap-up our preliminary analysis, immigration to Russia has played and will play a critical role in shaping current Russian society and its economy. In comparison Western countries, current migration between Russia and CIS countries has its distinctive components, which are mainly effected by the history of the former USSR.

Russia has become a large-scale recipient country for labour migrants from Central Asia. As the hosting region, Russia is struggling to maintain the size of its population which is declining every year. To a large extent, Russia has benefited from a demographic window of opportunity from labour migration flows from CIS countries, in particular of young people. As the sending region, due to unemployment and low wages, people from Tajikistan, Uzbekistan, and Kyrgyzstan travel to Russia in search for work to improve their quality of life. While those at home benefit from remittances sent back from these migrants.

It is worth mentioning that the wage differentials between Russia and CIS countries is diminishing slowly, but it will continue to determine migration from CIS countries in the next 10 - 15 years, according to our calibration results. The sending countries will continue to benefit from the wage gap. However, in the long run, the wage gap between Russia and some sending CIS countries will slowly diminish, meaning that certain countries are likely to switch from being a sending to a receiving country, like in the case of Kazakhstan.

Russia represents a fascinating new frontier of international migration, in which migration policy, labour market system, and people's attitudes, are all in ferment. As a policy issue, migration is seen to be significant in the context of an ageing population, future labour supply, and the prospects for economic growth as well as for its role in the deep and comprehensive integration in the Eurasian space. The model developed in this study can be useful to support policy on issues regarding strengthening the capacity and legal framework in managing migration, and increasing cooperation in managing regional migration mechanisms.

Currently, policy issues relevant to migration need to consider two dimensions in the context of the CIS region: 1) from Russia's point of view, how can Russian's migration policy really ensure a sufficient labour supply to meet the demands of its industrial development? That it not just about the quantity of labour, but also the quality of labour; 2) the migration flow from other CIS states have become firmly built into their national economies, providing recipient countries with the necessary workforce and simultaneously offering employment opportunities for their labour in other countries, thus, sustainable development and growth of the economic potential of the region as a whole is ensured. Therefore, strengthening regional intergovernmental cooperation in migration could create special conditions for the development of intergovernmental regional cooperation in migration.

This new migration network centred on Russia has entailed new policies and legislation for all the governments concerned. The establishment of 15 new states out of the former USSR led to the creation of new national citizenships, immigration rules, and methods of governing migration. Over the last 20 years, Russia, in particular has struggled to define its own goals for international migration. From an early policy of facilitating the naturalization of post-Soviet refugees, to a tightening of migration controls in the early 2000s that for a time drove effectively illegalized nearly all labour migration, the government of President Vladimir Putin has recently acknowledged that immigration is essential for Russia's economic development. Russia has accordingly liberalized some rules for its guest workers. However Russia still lacks policies to facilitate immigrant integration and create a positive official vision of a more multicultural society.

\section{Acknowledgements}

Authors would like to show the gratitude to IIASA for supporting this work, and to gratefully acknowledge the support from the Russian Foundation for Basic Research № 16-06-00048 "The social paradigm of regional development: the choice of priorities and the transformation of the economy".

\section{References}

[1] Genov, N. and Savvidis, T., Eds. (2011) Transboundary Migration in the Post-Soviet Space: Three Comparative Case Studies. Peter Lang GmbH, Internationaler Verlag der Wissenschaften.

[2] Gelbach, J.B. (2004) Migration, the Life Cycle, and State Benefits: How Low Is the Bottom? Journal of Political Economy, 112, 1091-1130. http://dx.doi.org/10.1086/422560 
[3] Ramirez, A.M. and Valiuniene, V.K. (2010) The Migration Flow in the Context of Deterioration of the Economic Factors. Economics and Management, 18, 479-484.

[4] Aleksashenko, S. (2015) The Russian Economy in 2050: Heading for Labor-Based Stagnation. http://www.brookings.edu/blogs/up-front/posts/2015/04/02-russia-economy-labor-based-stagnation-aleksashenko

[5] Wittgenstein Centre for Demography and Global Human Capital (2015) Wittgenstein Centre Data Explorer Version 1.2. www.wittgensteincentre.org/dataexplorer

[6] Ghatak, S., Levine, P. and Wheatley Price, S. (1996) Migration Theories and Evidence: An Assessment. Journal of Economic Surveys, 10, 159-198. http://dx.doi.org/10.1111/j.1467-6419.1996.tb00008.x

[7] Harris, J.R. and Todaro, M.P. (1970) Migration, Unemployment and Development: A Two-Sector Analysis. The American Economics Review, 60, 126-142.

[8] Hicks, J.R. (1963) The Theory of Wages. 2nd Edition, Macmillan, London. http://dx.doi.org/10.1007/978-1-349-00189-7

[9] OECD Report (2016) International Migrant Remittances and Their Role in Development. International Migration Outlook SOPEMI 2006 Edition.

[10] Oshchepkov, A.Y., Kholodilin, K. and Siliverstov, B. (2009) The Russian Regional Convergence Process: Where Does It Go? DIW Berlin, German Institute for Economic Research, Series 861 “Discussion Papers of DIW Berlin”, No. 861.

[11] Tapinos, G.F. (1974) L'economie de migration international. Fondation nationale des Sciences politiques, Paris.

[12] Sjaastad, L.A. (1962) The Costs and Returns of Human Migration. Journal of Political Economy, 70, 80-93. http://dx.doi.org/10.1086/258726

[13] Pickles, A. and Rogerson, P. (1984) Wage Distribution and Spatial Preferences in Competitive Job Search and Migration. Regional Studies, 18, 131-142. http://dx.doi.org/10.1080/09595238400185131

[14] Miron, J.R. (1978) Job Search Perspectives on Migration Behaviour. Environment and Planning A, 10, 519-535. http://dx.doi.org/10.1068/a100519

[15] Baba, B., Mc Gregor, P. and Jusoff, K. (2008) Today’s Relevancy of the Migration Determinants Theory. Asian Social Science, 4, 84-95.

[16] Iontsev, V. and Aleshkovski, I. (2007) International Migration, Globalization and Development. Migration and Development. Issue 20, Scientific Series 'International Migration of Population: Russia and Modern World'. BI El Print, Moscow. (In Russian)

[17] Irina, I. (2005) International Labour Migration Management-A Priority Vector of the Russian Migration Policies. In: Migration Processes Management in the Russian Federation, Gelios ARV, Moscow, 126-137.

[18] Bruni, M. (2009) Demographic Forecasts, Migration and Transition Theory: A Labor Market Perspective. Series of the Center for the Analysis of Public Policies (CAPP), Universita di Modena e Reggio Emilia, Dipartimento di Economia Politica, No 0070.

[19] Bijak, J., Kupiszewska, D., Kupiszewski, M., Saczuk, K. and Kicinger, A. (2007) Population and Labour Force Projections for 27 European Countries, 2002-2052: Impact of International Migration on Population Ageing. European Journal of Population, 23, 1-31. http://dx.doi.org/10.1007/s10680-006-9110-6

[20] Dustmann, C. and Preston, I. (2011) Estimating the Effect of Immigration on Wages. Northface Migration, Discussion Paper, No. 26.

[21] Dustmann, C., Casanova, M., Fertig, M., Preston, I. and Schmidt, C.M. (2003) The Impact of EU Enlargement on Migration Flows (Home Office Online Report 25/03). Research Development and Statistics Directorate, Home Office, London.

[22] Greenwood, M.J. (1997) Internal Migration in Developed Countries. In: Rosenzweig, M.R. and Stark, O., Eds., Handbook of Population and Family Economics, Vol. 1B, Elsevier, Amsterdam, 647-720. http://dx.doi.org/10.1016/S1574-003X(97)80004-9

[23] Freeman, R.B. (2006) People Flows in Globalization. NBER Working Paper No. 12315, NBER Program(s). http://www.nber.org/papers/w12315

[24] Dustmann, C. and Preston, I. (2011) Estimating the Effect of Immigration on Wages. CReAM Discussion Paper Series 1121, Centre for Research and Analysis of Migration (CReAM), Department of Economics, University College London, London.

[25] Longhi, S., et al. (2005) The Impact of Immigration on the Employment of Natives in Regional Labour Markets: A Meta-Analysis. ISER Working Paper 2006-10, Institute for Social and Economic Research, UK.

[26] Friedberg, R.M. and Hunt, J. (1995) The Impact of Immigrants on Host Country Wages, Employment and Growth. Journal of Economic Perspectives, 9, 23-44. http://dx.doi.org/10.1257/jep.9.2.23 
[27] Ottaviano, G.I.P. and Peri, G. (2006) Rethinking the Effects of Immigration on Wages. NBER Working Paper No. 12497, Cambridge.

[28] Borjas, G.J. (2009) The Analytics of the Wage Effect of Immigration. NBER Working Paper No. 14796.

[29] Sjaastad, L.A. (1962) The Costs and Returns of Human Migration. Journal of Political Economy, 70, 80-93.

\section{Submit or recommend next manuscript to SCIRP and we will provide best service for you:}

Accepting pre-submission inquiries through Email, Facebook, LinkedIn, Twitter, etc.

A wide selection of journals (inclusive of 9 subjects, more than 200 journals)

Providing 24-hour high-quality service

User-friendly online submission system

Fair and swift peer-review system

Efficient typesetting and proofreading procedure

Display of the result of downloads and visits, as well as the number of cited articles

Maximum dissemination of your research work

Submit your manuscript at: http://papersubmission.scirp.org/ 